\title{
PENGEMBANGAN E-MODUL PENDIDIKAN KEWARGANEGARAAN BERBASIS APLIKASI ANDROID
}

\author{
Sri Husnulwati ${ }^{1}$, Layang Sardana ${ }^{2}$, Suryati ${ }^{3}$ \\ ${ }^{123}$ Universitas PGRI Palembang, Palembang, Indonesia, \\ e-mail: srihusnulwati123@gmail.com
}

\begin{abstract}
Abstrak
Pemilihan media yang tepat tentu sangat berpengaruh terhadap berhasil tidaknya sebuah proses belajar mengajar. Modul sebagai salah satu media pembelajaran juga harus menyesuaikan, salah satu caranya dengan menggunakan modul elektronik (e-module). Adapun tujuan dari penelitian ini adalah untuk mengetahui, (1) pengembangan produk modul pembelajaran elektronik (e-modul) berbasis android untuk mata kuliah Pendidikan Kewarganegaraan, (2) kemenarikan, kemudahan dan kemanfaatan dari penggunaan produk modul pembelajaran elektronik (e-modul) berbasis android untuk mata kuliah Pendidikan Kewarganegaraan, (3) keefektifan penggunaan modul pembelajaran elektronik (e-modul) berbasis android untuk mata kuliah Pendidikan Kewarganegaraan. Subjek uji coba produk penelitian pengembangan ini terdiri atas ahli desain, ahli isi/materi pembelajaran, uji satu lawan satu (one for one) dan uji kelompok kecil. Metode penelitian yang digunakan, yaitu Research and Development atau penelitian pengembangan. Adapun hasil dari penelitian ini adalah, (1) Kualitas e-Modul Pendidikan Kewarganegaraan sebagai sumber belajar terkategori layak digunakan karena secara komponen baik media, materi dan proses pembelajaran mendapatkan skor masing-masing $67,00,150,00$ dan 88,20 yang terkategori sangat layak, (2) Kelayakan e-Modul Pendidikan Kewarganegaraan sebagai sumber belajar terkategori layak digunakan. Hal ini karena secara komponen baik, tampilan, pengoperasian, dan pewarnaan mendapatkan nilai masing-masing $63,33 \%$, $63,33 \%$ dan $86,63 \%$ yang jika direrata terkategori layak digunakan.
\end{abstract}

Kata kunci: e-modul, Pendidikan Kewarganegaraan, Android.

\begin{abstract}
The selection of the right media is certainly very influential on the success or failure of a teaching and learning process. Modules as one of the learning media must also adjust, one of the ways is by using electronic modules (e-modules). The purpose of this research is to find out, (1) the development of an electronic-based electronic learning module (e-module) for Citizenship Education courses, (2) the attractiveness, convenience and usefulness of the use of electronic-based learning module products (e-modules) android for Citizenship Education courses, (3) the effectiveness of the use of android-based electronic learning modules (e-modules) for Citizenship Education courses. The subjects of the research product development trial consisted of design experts, content experts / learning materials, one-to-one tests and small group tests. The research method used, namely Research and Development. The results of this study are, (1) The quality of the Civic Education eModule as a categorized learning resource is appropriate because the components both the media, the material and the learning process get scores of 67.00, 150.00 and 88.20 respectively. very feasible, (2) The eligibility of the Civic Education e-Module as a categorized learning resource is feasible to use. This is because in terms of good components, appearance, operation, and coloring get the values of $63.33 \%, 63.33 \%$ and $86.63 \%$ which, if categorized as appropriate, are suitable to be used
\end{abstract}

Keywords : e-module, Civics Education, Android. 


\section{Pendahuluan}

Penggunaan media dan sumber belajar merupakan bagian dari komponen yang mempengaruhi pembelajaran. Bahan ajar perlu disesuaikan dengan kondisi siswa dan strategi pembelajaran yang digunakan guru. Pemanfaatan dan pemberdayaan modul untuk menunjang pembelajaran merupakan suatu keniscayaan, bukan hanya untuk meningkatkan efektifitas dan kualitas pembelajaran, tetapi yang lebih penting adalah untuk meningkatkan penguasaan materi baik guru maupun siswa.

Berdasarkan orbsevasi yang dilakukan pada Program Studi Pendidikan Bahasa Inggris Universitas PGRI Palembang, masih banyak pengajar (dosen) yang menggunakan media dan metode konvensional dalam proses perkuliahan khususnya pada mata kuliah Pendidikan Kewarganegaraan pada Program Studi Pendidikan Bahasa Inggris Universitas PGRI Palembang. Banyak dosen yang masih menggunakan modul cetak serta metode ceramah sehingga bagi mahasiswa terasa membosankan. Hal ini juga berpengaruh dengan susahnya mahasiswa dalam mengulang pelajaran.

Pemilihan media yang tepat tentu sangat berpengaruh terhadap berhasil tidaknya sebuah proses belajar mengajar. Hal ini tentu karena pada proses belajar mengajar membutuhkan rasa suka dari diri mahasiswa sebagai peserta didik. Rasa suka sendiri dapat dimunculkan dari ketertarikan mahasiswa terhadap media pembelajaran yang menarik bagi mereka. Jika merujuk pada perkembangan teknologi informasi saat ini, tentu media pembelajaran harus juga dapat beradaptasi dengan perkembangan tersebut. Modul sebagai salah satu media pembelajaran juga harus menyesuaikan, salah satu caranya dengan menggunakan modul elektronik (e-module).

Hakikatnya modul hendaklah menjadi sumber informasi yang mudah dicermati dan digunakan. Pada dasarnya media adalah semua bentuk perantara yang digunakan oleh manusia untuk menyampaikan atau menyebar ide, gagasan, atau pendapat sehingga ide, gagasan, atau pendapat yang dikemukakan itu sampai kepada penerima yang dituju . Modul sebagai sebuah media yang baik seharusnya adalah media yang cara penggunaanya mudah dioperasikan, instruksi yang disampaikan mudah dimengerti dan mudah ditanggapi oleh peserta didik (mahasiswa). Penyajian bahan ajar, bahasa yang digunakan membuat mahasiswa merasa akrab dengan modul serta termotivasi untuk mempelajarinya, karena salah satu karakteristik modul adalah user friendly.

Elektronik Modul dalam Pembelajaran dirancang untuk memberikan pengalaman belajar yang melibatkan proses mental dan fisik melalui interaksi antar peserta didik, peserta didik dengan dosen, lingkungan dan sumber belajar lainnya dalam rangka mencapai kompetensi dasar. Pengalaman belajar yang dimaksud dapat terwujud melalui penggunaan bahan ajar yang bervariasi dan berfokus atau berpusat pada kondisi dan kepentingan peserta didik. Pengalaman belajar memuat kecakapan hidup yang perlu dikuasai peserta didik. Oleh karena itu, inti dari pembelajaran adalah bagaimana proses belajar itu terjadi pada diri peserta didik.

Menurut Bambang (2008: 86) mengemukakan kegiatan belajar hanya bisa berhasil jika peserta didik belajar secara aktif mengalami sendiri proses belajar. Kegiatan pembelajaran ini akan menjadi bermakna bagi peserta didik jika dilakukan dalam lingkungan yang nyaman dan memberikan rasa aman bagi peserta didik.

Modul merupakan salah satu bahan ajar yang dapat digunakan peserta didik dalam pembelajaran. (Depdiknas, 2008: 19) modul adalah seperangkat bahan ajar yang disajikan secara sistematis sehingga penggunanya dapat belajar dengan atau tanpa fasilitator/guru. Modul elektronik adalah modul yang berbentuk digital yang dapat berwujid teks, gambar, audio, maupun animasi yang dibaca pada komputer atau alat pembaca digital lainnya. Penggunaan modul dalam pembelajaran dapat membantu memfasilitasi kegiatan belajar peserta didik untuk mencapai tujuan pembelajaran. Modul elektronik memiliki banyak kelebihan, diantaranya mampu menyajikan modul dengan lebih menarik. Dan diharapkan dengan penggunaan modul elektronik dapat meningkatkan minat, motivasi, keaktifan serta mampu meningkatkan pemahaman peserta didik terhadap pembelajaran. 
E-modul dapat disusun dengan aplikasi multimedia karena dapat memadukan berbagai media (format file) yang berupa teks, gambar, grafik, musik, animasi, video, dan interaksi menjadi file digital (komputerisasi), serta digunakan untuk menyampaikan pesan kepada pengguna. Aplikasi multimedia dapat menghasilkan media pembelajaran yang lebih menarik, dan lebih interaktif. Selain itu, jumlah waktu mengajar dapat dikurangi dan proses belajar dapat dilakukan dimana saja dan kapan saja .

Beranjak dari latar belakang tersebut, maka penulis mencoba mengembangkan " $E$ Modul Berbasis Android Sebagai Sumber Belajar Mata Kuliah Pendidikan Kewarganegaraan".

\section{Metode}

Metode penelitian yang digunakan, yaitu Research and Development atau penelitian pengembangan. Pengembangan yang dilakukan yaitu, berupa pembuatan modul pembelajaran berbasis aplikasi android pada mata kuliah Kewarganegaraan di Program Studi Pendidikan Bahasa Inggris. Modul yang dikembangkan dapat digunakan sendiri oleh mahasiswa ataupun dengan bimbingan dosen. Subjek uji coba produk penelitian pengembangan ini terdiri atas ahli desain, ahli isi/materi pembelajaran, uji satu lawan satu (one for one) dan uji kelompok kecil sebagai berikut :

1) Uji ahli desain, yaitu seorang yang ahli dalam bidang teknologi pendidikan terkait evaluasi desain modul, 2) Uji ahli bidang isi/materi dilakukan oleh ahli bidang isi atau materi yaitu seorang yang berlatar belakang IImu Kewarganegaraan, 3) Uji satu lawan satu, yaitu diambil sampel penelitian 3 orang mahasiswa yang dapat mewakili populasi target, 4) Uji kelompok kecil, yaitu diambil sampel penelitian satu kelas mahasiswa program studi Pendidikan Bahasa Inggris dimana sampel diambil dari semua anggota populasi.

Uji coba dilakukan untuk mendapatkan tanggapan kemenarikan dan keefektifan dari elektronik modul yang telah dikembangkan. Penelitian dilaksanakan pada semester Genap tahun akademik 2018/2019 di Prodi Pendidikan Bahasa Inggris, Fakultas Keguruan dan IImu Pendidikan (FKIP) Universitas PGRI Palembang.

\section{Hasil dan Pembahasan}

Hasil

Penelitian ini bertujuan untuk mengetahui kualitas kelayakan dan unjuk kerja e-Modul Pendidikan Kewarganegaraan sebagai sumber belajar mata kuliah Pendidikan Kewarganegaraan. Penilaian diambil dari komponen materi, media dan proses pembelajaran. Sedangkan unjuk kerja dinilai dari aspek tampilan atau layout, pewarnaan dan pengoperasian. Penilaian dilakukan menggunakan angket dengan empat pilihan jawaban dimana skor terendah adalah 1 dan tertinggi adalah 4 . Skor tersebut kemudian dikonversikan kedalam kategori kelayakan sesuai dengan yang terdapat pada analisis data.

Aplikasi e-Modul Pendidikan Kewarganegaraan dinyatakan layak apabila rerata kelayakannya mencapai kriteria "cukup layak". Pembahasan meliputi pembahasan kelayakan e-Modul dan unjuk kerja e-Modul sebagaimana yang terdapat pada rumusan masalah. Berikut juga disampaikan gambaran hasil e-Modul Pendidikan Kewarganegaraan : 


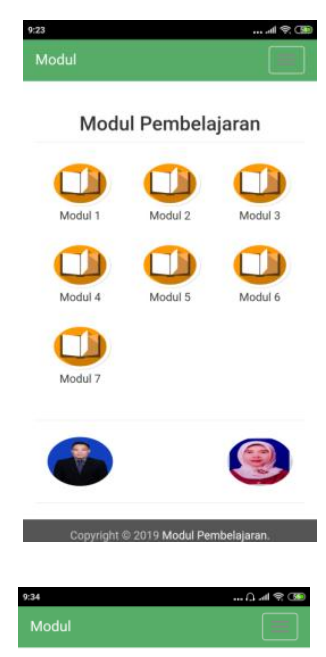

Modul 4

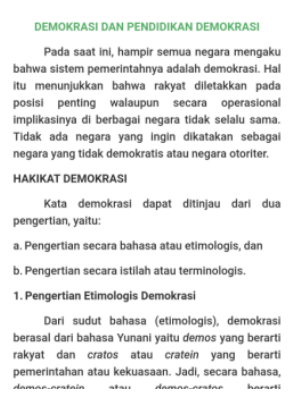

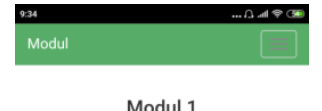

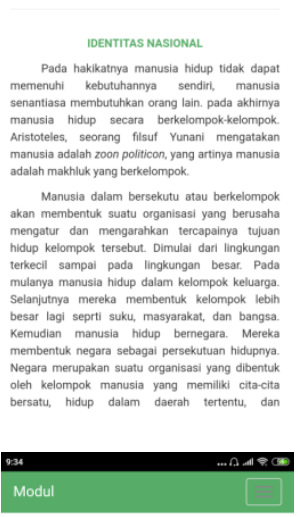

Modul 5

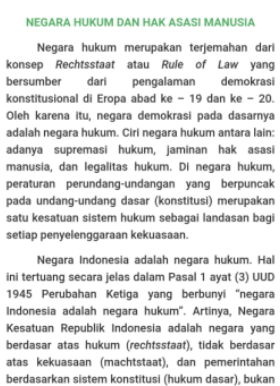

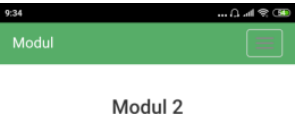
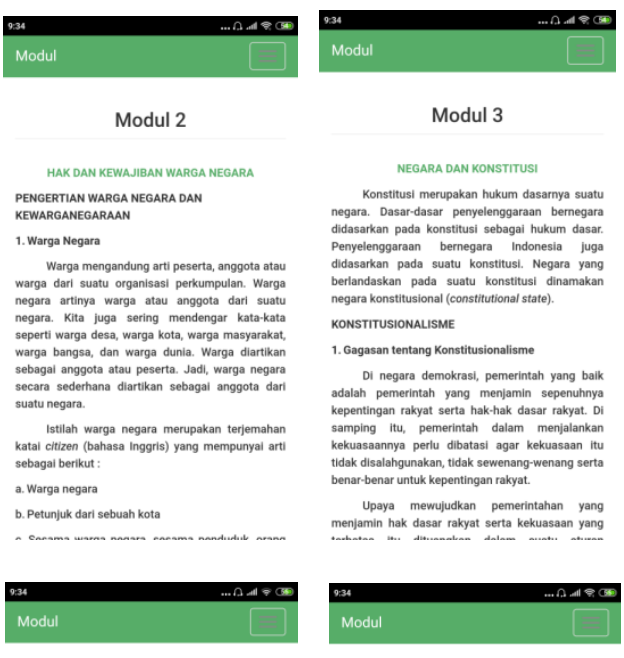

Modul 6

Modul 7
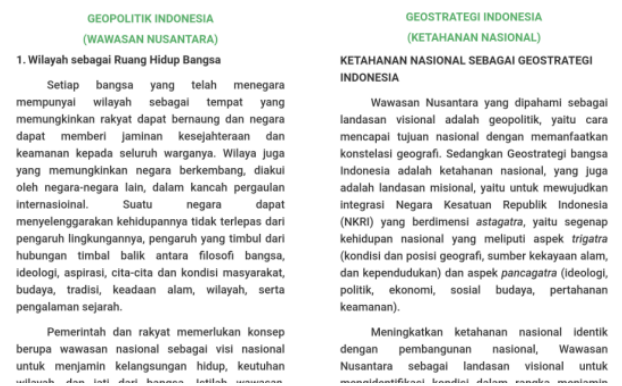

Gambar 1. Layout e-Modul Pendidikan Kewarganegaraan

\section{Kualitas e-Modul}

Kualitas e-Modul ditinjau dari komponen: (a) materi, (b) media, (c) proses pembelajaran.

\section{a. Pembahasan Evaluasi Ahli Materi}

Penilaian ahli materi meliputi aspek self instruction, self contained, adaptive dan user friendly. Aspek-aspek tersebut kemudian disusun dan dihitung berdasar kategori kelayakan. Perhitungan dapat dilihat pada lampiran. Hasil data ahli materi seperti yang terlihat pada diagram berikut.

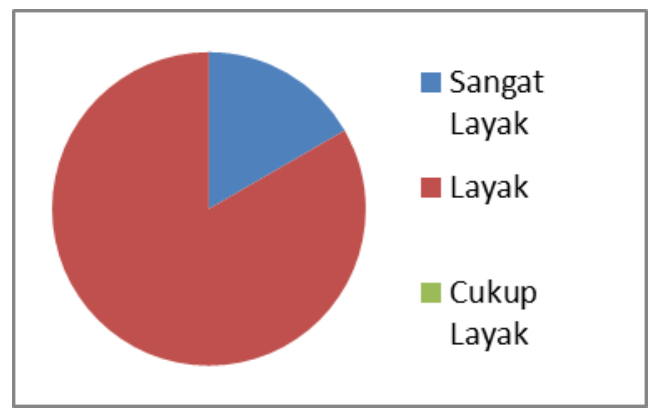

Gambar 1. Diagram Hasil Penilaian Ahli Materi

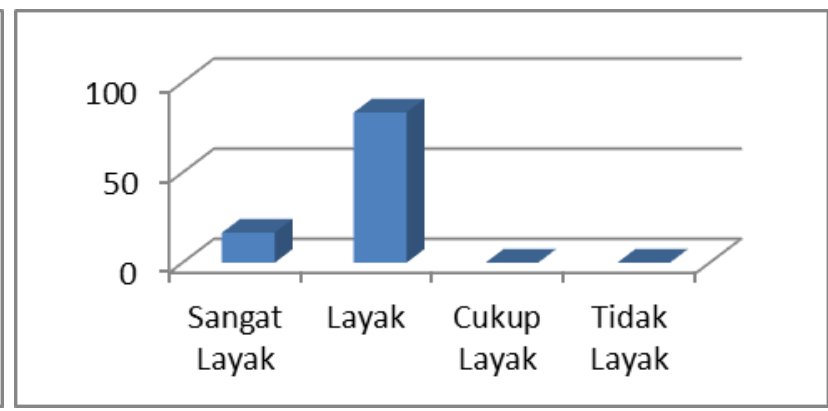

Gambar 2. Kategori Kelayakan Aspek-Aspek Materi 
Terlihat pada Gambar 1, bahwa aspek materi 100\% termasuk dalam kategori "layak", dengan demikian maka secara otomatis modul pembelajaran termasuk "sangat layak" pada aspek materi.

Aspek self instruction, self contained dan adaptive, user friendly masing-masing mendapatkan kategori sangat layak (100\%). Berdasar penilaian ahli materi maka e-Modul Pendidikan Kewarganegaraan sebagai sumber belajar Pendidikan Kewarganegaraan termasuk dalam kategori "layak" pada aspek materi.

Aplikasi e-Modul pembelajaran layak digunakan karena dari semua aspek materi memenuhi kriteria kelayakan modul. Aspek self instruction memenuhi kriteria sangat layak karena modul pembelajaran memuat hal-hal sebagai berikut : (a) modul mempunyai kejelasan terkait tujuan pembelajaran, (b) materi dikemas secara runut, (c) materi pembelajaran didukung dengan contoh dan ilustrasi, (d) tersedia soal-soal dan tugas untuk mengukur penguasaan peserta didik, (e) tugas dan soal yang disajikan relevan dengan materi, konteks kegiatan dan lingkungan peserta didik, (f) penggunaan bahasa yang sederhana dan komunikatif, (g) tersedia rangkuman materi pembelajaran, (h) tersedia instrumen penilaian. Aspek self contained memenuhi kriteria sangat layak karena modul pembelajaran memuat seluruh materi pembelajaran secara utuh. Aspek adaptive memenuhi kriteria sangat layak karena e-Modul mengadaptasi perkembangan teknologi. Aspek user friendly memenuhi kriteria sangat layak karena modul pembelajaran memuat instruksi dan informasi yang mudah digunakan.

\section{b. Pembahasan Evaluasi Ahli Media}

Penilaian ahli media meliputi aspek organisasi, daya tarik, huruf dan gambar. Aspekaspek tersebut kemudian disusun dan dihitung berdasar kategori kelayakan. Perhitungan dapat dilihat di Lampiran. Hasil persebaran data dapat dilihat pada diagram dibawah.

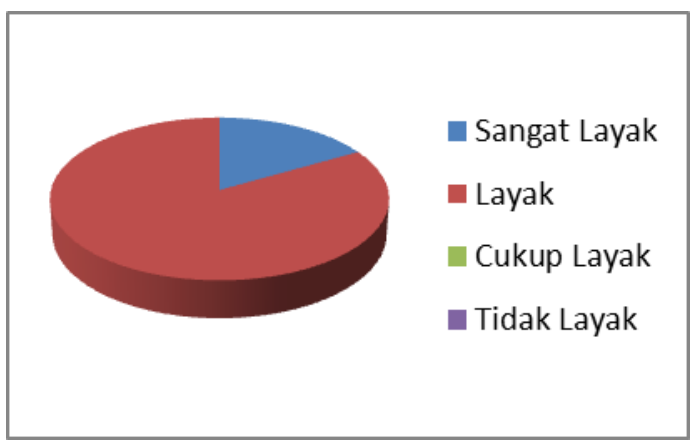

Gambar 3. Diagram Hasil Penilaian Ahli Media

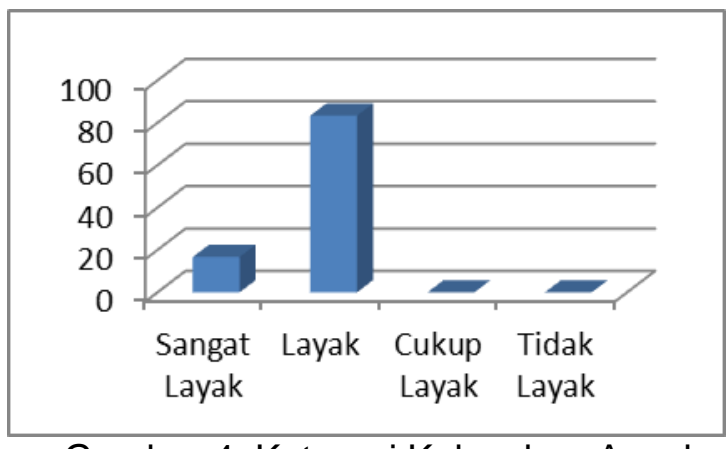

Gambar 4. Kategori Kelayakan Aspekaspek Media

Aspek organisasi dan daya tarik termasuk kategori sangat layak (100\%). Aspek huruf dan gambar menghasilkan kategori layak (50\%). Berdasarkan penilaian ahli media terkait eModul Pendidikan Kewarganegaraan sebagai sumber belajar mata kuliah Pendidikan Kewarganegaraan dari aspek media termasuk dalam kategori sangat layak.

Aplikasi e-Modul Pendidikan Kewarganegaraan layak digunakan karena dari semua aspek media memenuhi kriteria kelayakan modul. Aspek organisasi memenuhi kriteria sangat layak karena modul pembelajaran memuat keterbacaan teks pada e-Modul dan kelengkapan bagian-bagian modul. Aspek daya tarik termasuk termasuk kategori sangat layak karena e-Modul memuat hal-hal sebagai berikut: (a) kemenarikan penampilan isi modul, (b) kemenarikan penampilan soal-soal, (c) pemberian gambar, ilustrasi dan animasi. Aspek huruf dan gambar memenuhi kriteria layak karena e-Modul mempunyai warna huruf, gambar dan bentuk huruf yang sesuai. 


\section{c. Pembahasan Kualitas e-Modul Proses Pembelajaran}

Kualitas aplikasi e-Modul pada proses pembelajaran dapat terlihat ketika digunakan dalam kegiatan pembelajaran. Langkah-langkah pembelajaran dilaksanakan sesuai dengan tahapan Rencana Pelaksanaan Pembelajaran seperti yang terlampir pada Lampiran.

Persebaran distribusi frekuensi berdasar kelayakan dalam bentuk diagram adalah sebagai berikut.

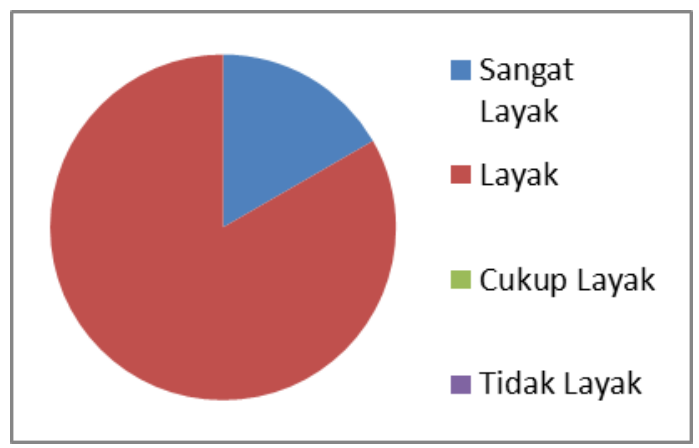

Gambar 5. Diagram Kualitas e-Modul Pada Proses Pembelajaran

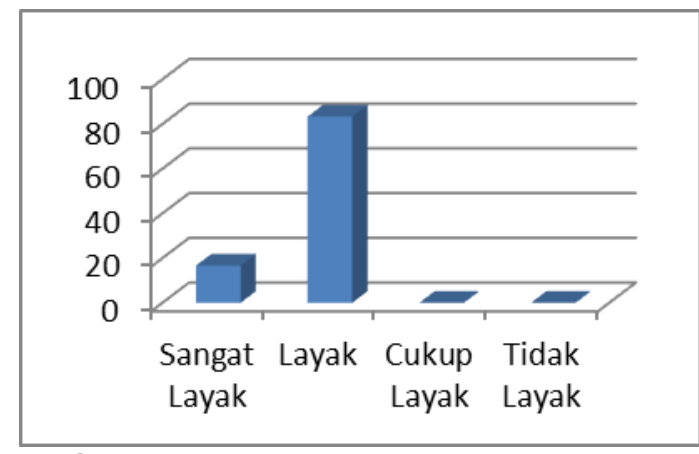

Gambar 6. Kategori Kelayakan Aspek Proses Pembelajaran

Dari hasil diatas dapat terlihat bahwa kategori "sangat layak" mendapatkan persentase sebesar $15 \%$, kategori "layak" mendapatkan persentase sebesar $77 \%$, kategori "cukup layak" sebesar $8 \%$ dan kategori "tidak layak" sebesar $0 \%$. Kualitas e-Modul pada proses pembelajaran termasuk kategori layak.

Kualitas e-Modul pada proses pembelajaran menghasilkan kriteria layak karena aspek materi, aspek media dan proses pembelajaran memenuhi kriteria kelayakan. Aspek materi dinilai sangat layak karena e-Modul Pendidikan Kewarganegaraan mengandung hal-hal sebagai berikut: (a) relevansi materi e-Modul, (b) soal-soal yang disediakan, (c) bahasa dalam penyampaian materi. Aspek media dinilai layak karena e-Modul memuat hal-hal sebagai berikut: (a) keterbacaan teks atau tulisan dalam penampilan e-Modul, (b) gambar, ilustrasi, dan animasi, (c) komposisi warna. Aspek pembelajaran menggunakan e-Modul dinilai layak karena dalam proses pembelajaran e-Modul memenuhi ketertarikan pada modul dan kegiatan pembelajaran.

\section{Kelayakan e-Modul}

Kelayakan e-Modul dapat terlihat ketika digunakan dalam kegiatan pembelajaran ditinjau dari aspek (a) tampilan/layout, (b) pewarnaan, (c) pengoperasian dalam small group test. Indikator penilaian small group test terdiri atas ketertarikan pada e-Modul dan kegiatan pembelajaran. Persebaran distribusi kelayakan dari small group test dalam bentuk diagram adalah sebagai berikut.

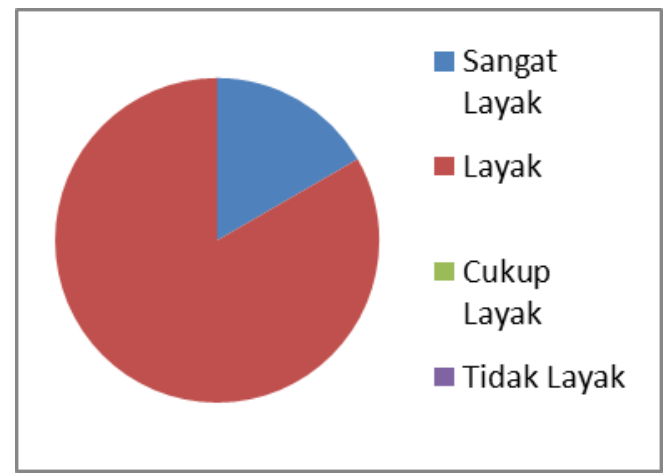

Gambar 7. Diagram Hasil Penilaian Small Group Test

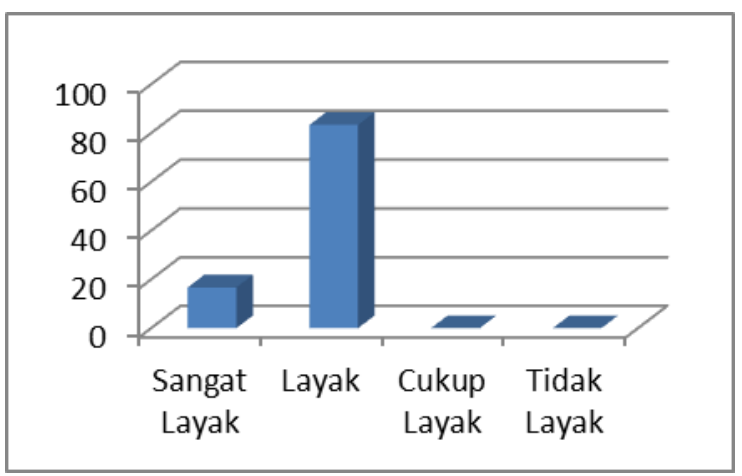

Gambar 8. Hasil Penilaian Small Group Test 
Tes Small Group menghasilkan sangat layak 17\% dan kategori layak 18\%. Dengan demikian unjuk kerja dari aspek tampilan/layout, pewarnaan dan pengoperasian termasuk kategori layak. Aspek tampilan, teks, gambar, animasi dan simulasi termasuk kategori layak (63\%). Aspek pewarnaan termasuk kategori layak (63,33\%). Aspek pengoperasian termasuk kategori layak (86,67\%).

Small group test dinilai layak karena dari semua aspek memenuhi kriteria kelayakan eModul. Small group test memenuhi kriteria layak karena hal-hal sebagai berikut: (a) keterbacaan teks atau tulisan dalam penampilan e-Modul, (b) menampilkan gambar, ilustrasi dan animasi, (c) komposisi warna, (d) ketertarikan pada modul, dan (e) kegiatan pembelajaran.

\section{Simpulan dan Saran}

Berdasarkan hasil penelitian, maka dapat ditarik kesimpulan sebagai berikut:

1. Kualitas e-Modul Pendidikan Kewarganegaraan sebagai sumber belajar mata kuliah Pendidikan Kewarganegaraan di Program Studi Pendidikan Bahasa Inggris Universitas PGRI Palembang layak digunakan ditinjau dari :

a. Komponen media termasuk kategori sangat layak dengan rerata skor 67,00 dari skor maksimal 80,00 dengan distribusi frekuensi layak dan sangat layak masing-masing sebesar $50 \%$.

b. Materi termasuk kategori sangat layak dengan nilai rerata 150,5 dari skor maksimal 160,00 dengan persentase sangat layak $100 \%$.

c. Proses pembelajaran termasuk kategori layak dengan rerata skor 88,2 dari skor maksimal 120,00 dengan persebaran distribusi frekuensi 7,69\%, dengan rata-rata kelayakan adalah kategori "layak".

2. Kelayakan e-Modul Pendidikan Kewarganegaraan sebagai sumber belajar mata kuliah Pendidikan Kewarganegaraan di Program Studi Pendidikan Bahasa Inggris Universitas PGRI Palembang layak digunakan ditinjau dari :

a. Tampilan teks, gambar, animasi, ilustrasi dan simulasi termasuk kategori layak dengan skor 23,35 dari skor maksimal 32,00. Rincian dari kelayakan tersebut adalah 11 siswa $(36,67 \%)$ mengatakan "sangat layak", 19 siswa (63,33\%) mengatakan "layak".

b. Pengoperasian termasuk kategori layak dengan rerata skor 25,62 dari skor maksimal 36,00 . Rincian dari kelayakan tersebut adalah 4 siswa $(13,33 \%)$ mengatakan "sangat layak", 19 siswa $(63,33 \%)$ mengatakan "layak", 7 siswa $(23,33 \%)$ mengatakan "cukup layak".

c. Pewarnaan termasuk kategori layak dengan rerata skor 8,27 dari skor maksimal 12,00. Rincian dari kelayakan tersebut adalah 3 siswa (10\%) mengatakan "sangat layak", 26 siswa (86,63\%) mengatakan "layak", 1 siswa (3,33\%) mengatakan "cukup layak".

\section{Saran}

Pengemabangan e-Modul Pendidikan Kewarganegaraan sebagai sumber belajar mata kuliah Pendidikan Kewarganegaraan di Program Studi Pendidikan Bahasa Inggris Universitas PGRI Palembang memiliki beberapa keterbatasan diantaranya :

1. Penyebaran dan penggunaan masih terbatas yaitu hanya di Universitas PGRI Palembang khususnya pada Program Studi Pendidikan Bahasa Inggris. Hal ini terkait materi dan silabus yang dipakai.

2. Belum dilengkapinya e-Modul dengan video animasi sehingga interaksi belum optimal. 


\section{Daftar Pustaka}

Arsyad. 2006. Media Pembelajaran. Jakarta: Raja Grafindo Persada

Bambang Warsita. 2008. Teknologi Pembelajaran : Landasan dan Aplikasinya. Jakarta : PT Rineka Cipta

Depdiknas. 2004. Pedoman Khusus Penyusunan Modul Sekolah Menengah Atas. Direktorat Pendidikan Menengah Umum: Depdiknas.

--------. 2008. Penulisan Modul. Jakarta: Direktorat Tenaga Kependidikan. Ditjen PMPTK: Depdiknas.

2008. Panduan Pengembangan Bahan Ajar. Direktorat Pembinaan Sekolah Menengah Atas.

2008. Penulisan Modul. Jakarta: Direktorat Tenaga Kependidikan. Ditjen PMPTK : Depdiknas.

Sugianto, et all. 2013. Modul Virtual: Multimedia Flipbook Dasar Teknik Digital. Jurnal INVOTEC, Volume IX, No. 2, Agustus 2013: 101-16. 